\title{
DISCOVERY LEARNING IN TEACHING REPORT WRITING FOR JUNIOR HIGH SCHOOL STUDENTS BASED ON 2013 CURRICULUM
}

\author{
Dina Amaliyah Mushtoza \\ Email:dhyna_am@ymail.com \\ Sekolah Tinggi Teknik Qomaruddin Gresik
}

\begin{abstract}
This study focuses on how the implementation of DL in teaching report writing for junior high school students based on 2013 curriculum. It has three research questions: (1) how is the implementation of DL in teaching report writing, (2) how are the students' responses towards DL during the teaching learning of report writing, (3) how is the students' writing report after taught by implementation of DL. This study used qualitative research. It focuses on natural setting, has an interest in meaning, the perspective emphasizes on a process, concern with an inductive analysis and grounded theory. The data collection techniques are observation and interview to anstablewer the first and second research questions, and documentation to answer first and third research questions. The result of this study reveals when teaching report writing, the teacher implements DL which is relevant and appropriate with the theories. He uses six steps, (1) stimulation (2) problem statement (3) data collection (4) data processing (5) verification (6) generalization. The students' responses are positive in five steps, except data processing, the students' response is negative, because of limited time. In all of the writing, the teacher gives his comments. It makes students pay attention to their result, and know their mistakes as motivational correction for them. All of students' score is still high of the standard score.
\end{abstract}

Key Words: Discovery Learning (DL), Teaching Report Writing, Junior High School Students, 2013 Curriculum

\section{INTRODUCTION}

English teaching should cope with the students to address the emergence of the global era which needs the ability to communicate particularly in English. It is generally accepted that the demand of English is not only to read, listen, and speak but also write. Writing skill involves thinking process to deliver message to communicate meaningfully (Hedge, 2000, p. 302). 
In fact, many students in junior high school have difficulties in writing. It seems get less attention from teacher among the three order skills of reading, speaking, and listening. Widayanti (2011) finds that some students get difficulties in expressing ideas and developing the topic. They feel hard to start writing. Besides, vocabulary also becomes a burden for them. Cahyaningsih (2013) find that students get problems in grammar, exploring ideas, writing mechanisms, text organization, and coherence.

Teachers should encourage their students to develop their writing skill. Task of teachers in the classroom are demonstrating, motivating and provoking, responding, and evaluating of students' writing (Harmer, 2004, p. 41). Since the 2013 curriculum is a new in Indonesia, it arouse some questions among the teachers how to implement it in English classroom. Some of them think that Scientific Approach (SA) uses in the 2013 curriculum is only suitable for teaching science, and it is so hard to be implemented in teaching a language. The curriculum is claimed as a new promising one with primary goal emphasizes that teaching is preparing Indonesian people to have life skill as an individual and citizen that is faithful, productive, creative, innovative, affective, and able to give contribution toward society and nation (Kemendikbud, 2013d).

It is prompted by the use of one models of teaching in order to improve the teaching development; one of them is called Discovery Learning (DL) (Kemendikbud, 2013f). The ability to conduct several stages of DL in teaching English becomes an obligation for teacher. Some workshops and trainings have been done in order to share the information about it. But, both teacher and students actually find the difficulties in the implementation especially in making students write well and interested in English lesson.

In junior high school level, teachers must assist classroom to review and refine the teaching of report writing actually in ninth level. Report texts are the most common factual genres encountered by students across the curriculum. The purpose of a report is to provide accurate and relevant information. Report writing is a genre which intends to classify and describe the natural, cultural and technological phenomena of our world (eg Computers) in contrast to a description 
which focuses on one specific thing (eg My Computer). So that, it is the most difficult genre for junior high school students than five others: descriptive, narrative, procedure, recount, and functional text. The report text is stated in basic competence number 3.2 with the content of:

"Basic competence is to respond the meaning in the short and simple monologue accurately, fast, receptively for interacting in the life context on a day to day basis in the procedure and report" (Kemendikbud, 2013e).

The language in a report text is influenced by the purpose of the author, audience, identity and stance of the author, as well as attitude (Department for Education and Development of South Australia, 2011). Therefore, teaching and learning report writing class for junior high school is challenging. Classes combine the teacher's need to explain and demonstrate with a student's need to practice and implement. Students end up working at different paces with markedly different levels of understanding which also makes the classes difficult and time consuming to teach and reach the most important goal of writing class is to enable them to develop an effective writing process, so that they can continue to learn after the class is ended (Clark, 2003, p. 1). In this case, they should be able to generate and organize the ideas then translate them into readable text or writing (Reppen, 2002). However, students in junior high students are still in the transitional phase between childhoods and adolescent who have begun to master the complex sentences.

To overcome this, DL which directs students to interact, seek answers to a question by way of collaborating is expected according to the stages of age students at the junior high level. It needs to be fixed note that the essence of learning English is as a communication tool. So the activities in the DL should accommodate the needs of students to use language as a communication tool, instead of studying the language itself.

However, DL cannot be called new brand. The first reference about it was mentioned in the work of Jerome Bruner that argues that "Practice in discovering for oneself teaches one to acquire information in a way that makes that information more readily viable in problem solving" (Bruner, 1961, p. 26). In recent EFL methods, DL is close 
with OHE method by Lewis in 1986 . He claims that students should be allowed to 'observe' (read or listen to language) which will then provoke them to 'hypothesis' about how the language works before going on to 'experiment' on the basis of that hypothesis (Lewis in Harmer, 1998). It such a description is close to the Triple I of McCarthy and Carter (1995) in Harmer (1998) where they show students examples of language like the transcripts of conversations means 'illustration', then they give them discovery activities and questions about the language, as a result of which means 'interaction', then through such a noticing routine, students will grasp new facts about language means 'induction'.

In Indonesia, DL is close with Contextual Teaching and Learning (CTL). It is a conception of teaching and learning that helps teachers relate subject matter content to real world situations; and motivates students to make connections between knowledge and its applications to their lives as family members, citizens, and workers and engage in the hard work that learning requires. Kemendikbud (2013d) also mentions that DL has the same principle as the inquiry. There is no difference of principle on these two terms, the DL more emphasis on the discovery of a concept or principle that was previously unknown.

As the term DL is a new method using in English teaching in Indonesia, it is important to investigate how it is implemented by teachers in the classroom. Report writing is product a text report which presents information about something as a result of systematic observation and analysis. Students need to know about how language is used to structure factual text and the language features used in a report to achieve its purpose. Students also need to develop an understanding of how different audiences and purposes of reports determine the language choices they make. However, DL is a method where the learner draws on his own experience and prior knowledge. It is a method of instruction through which students interact with their environment by exploring and manipulating objects, wrestling with questions and controversies, or performing experiments. DL's stages are: (1) Stimulation, (2) Problem Statement, (3) Data Collection, (4) Data Processing, (5) Verification, (6) Generalization. Therefore, teaching report writing can be applied with DL as a method where the 
learner draws on his own experience and prior knowledge. It is an instruction through which students interact with their environment by exploring and manipulating objects, wrestling with questions and controversies, or performing experiments.

\section{RESEARCH METHOD}

The suitable design of this research was qualitative research. The researcher conducts this research in one of State Junior High School in Gresik that was chosen by the government to be one of the pilot project schools which implemented the 2013 curriculum in Gresik since October 2013, and was found one of teacher implemented it in the classroom as one of the method used. He also becomes teacher guide for other teachers in the implementation the 2013 curriculum.

To gain the detail information and data, the researcher used three research instruments: observation, interview, and documentation. Observation was measurement method to scrutinize all the events represented by the teacher's and students' verbal and non verbal behavior and also students' response during the teaching learning process using DL in teaching report writing from the beginning till the end. It was done for several times. Observation sheet covered teacher's certain behaviors that consist of certain activity and also students' responds during the teaching learning process. Video recording was used to record the whole process of activities to get some additional information which was not covered in the observation sheet. Interview was used to expand the more information from the teacher relating with the teacher's background information relating with DL, preparation in implementing DL for report writing, how the teacher conducted the model of teaching as well as prepare the students and materials, and also how to assess the teaching of report writing through DL. Besides, the researcher also tried to deepen the information from the students as a method the effectiveness of the DL implementation after the class. Documentation was written instrument used to complete the information that was got from the students' product of report writing in form of wall magazine creative writing.

Then, all findings were described and analyzed qualitatively and inductively selected and focused on the data. It contains of the category 
of how the teacher implemented DL in teaching and learning report writing, student learning in teaching and learning report writing, student response during the implementation of DL, and the result of the students' report writing. After jotting down the observation sheet and making transcription from the interview, all data from both source were analyzed and selected as to which data belonged to the most important data needed to answer the three research questions.

The data also was supported by the recording of the lesson that has been coded used action to decide the categorization data. This process was needed to make the data categories in order to make researcher easier to take the next action. After having data categories, it was analyzed. This sort of stage considered as data interpretation. The researcher was not only analyzing the data using the prespective but also correlate it with the theory.

It was the last step of DL when the teacher gave the conclusion of the whole activities in the class. Students could get deep understanding and became an active students through the whole activities because they got direct interaction when the teaching and learning process run.

To summarize the implementation of DL in teaching report writing of the whole steps, researcher put it into the summary table like in the following table 1 :

Table 1 Summary Table of the Implementation of DL in Teaching Report Writing

\begin{tabular}{|c|c|c|}
\hline Step & Activities & \multicolumn{1}{c|}{ Comments } \\
\hline Stimulation & $\begin{array}{c}\text { Relevant with the } \\
\text { theory }\end{array}$ & $\begin{array}{l}\checkmark \text { It helped students' identifying topic } \\
\checkmark \text { It encouraged the students to write } \\
\text { achieving the goal }\end{array}$ \\
\hline $\begin{array}{c}\text { Pro } \\
\text { blem } \\
\text { Statement }\end{array}$ & $\begin{array}{c}\text { Relevant with the } \\
\text { theory }\end{array}$ & $\begin{array}{l}\checkmark \text { It helped students to know the } \\
\text { process of writing report text } \\
\text { through the model text }\end{array}$ \\
\hline $\begin{array}{c}\text { Data } \\
\text { Collection }\end{array}$ & $\begin{array}{c}\text { Relevant with the } \\
\text { theory }\end{array}$ & $\begin{array}{l}\checkmark \text { It gave opportunity to students to } \\
\text { explore as could as possible }\end{array}$ \\
\hline
\end{tabular}




\begin{tabular}{|c|c|c|}
\hline $\begin{array}{c}\text { Data } \\
\text { Processing }\end{array}$ & $\begin{array}{c}\text { Relevant with the } \\
\text { theory }\end{array}$ & $\begin{array}{l}\checkmark \text { It gave opportunity to students to } \\
\text { process the data }\end{array}$ \\
\hline Verification & $\begin{array}{c}\text { Relevant with the } \\
\text { theory }\end{array}$ & $\begin{array}{l}\checkmark \text { It gave opportuity to students to get } \\
\text { correction }\end{array}$ \\
\hline $\begin{array}{c}\text { Gene } \\
\text { raliza } \\
\text { tion }\end{array}$ & $\begin{array}{c}\text { Relevant with the } \\
\text { theory }\end{array}$ & $\begin{array}{l}\checkmark \text { It gave opportunity to students to } \\
\text { get the concept just not the } \\
\text { hypothesis }\end{array}$ \\
\hline
\end{tabular}

The summary table above showed the DL implementation in teaching and learning process in writing report text. It concluded that all the six steps were relevan with the theory of DL implementation.

It could be discussed that the activities in stimulation step was appropriate and relevant with the theory of stimualtion. Teacher was asking questions about a general topic interconnected with report text. He was also presenting picture in the stimulation step. He did not introduced directly. Using picture and visualization provided texts to help the students identifyed and wrote report writing. It indicated that he also lead to the preparation of solving. Shah (2004, p. 244) said that teacher started teaching learning activities by asking questions, suggestions reading books, and other learning activities that lead to the preparation of solving.

It also encouraged the students to write, especially in report writing. It is in line with Bruner in Norman and Richard Sprinthall (1990, p. 248) provides stimulation to use questioning is to ask questions that can expose the students to the internal conditions that encourage exploration. Teacher can provide the condition in which DL is nourished and will grow. One way can be done by students is to guess at answers and let the class know they are guessing. Stimulation at this step served to provide learning interaction condition that could develop and assist students in exploring materials.

Here, the teacher mastered the techniques of giving a stimulus to the students to enable in exploring the goal can be achieved. They are faced with something that causes confusion, then proceed to not give a generalization, so the desire to investigate itself (Taba in Affan, 1990, p. 198). Besides, it was same as As Djamarah opinion (2002, p. 22) that: 
These stages the teacher asked by proposing problems, or has students read or listen to a description that contains the problems.

In problem solving step, it was also appropriate with the theory. The teacher presented pictures to help students' general image to communicatie meaningfully. Moreover, it is the same a Haynes and Zakarian (2010, p.89) which tends to focus on communicating meaningfully in writing. The teacher also presented a text. It represented a model of a certain report text. The model of the report text is imporrtant for the students in Junior High School. It assisted them to write a report text. It has the same core with Hasan and Akhand (2010) in the teaching writing of a product approach. The product approach promotes the students to imitate a model text. In addition, the teacher also implemented teaching writing of the process approach. To conduct it, the teacher carried out the teaching writing by using varied activities such as problem statement activity to encourage students' write. It tends to focus more on varied classroom activities which promote the development of language use (Steele, 2004).

Through picture and text, teacher gave students the opportunity to identify and analyze their problem face. It was a useful technique in building students so that they were accustomed to find a problem. As Bruner opinion that: the students can then analyze the teacher's answer. It means is exploration can be both rewarding and safe. It is a valuable technique for building lifelong habits discovery in the student (Norman and Richard Sprinthall, 1990, p. 248).

The activity gave teachers an opportunity to the students to identify as many agenda issues relevant to the subject matter, then one of them is selected and formulated in the form of hypotheses (temporary answer to the question of issue). In line with Djamarah (2002, p. 22) was subsequently selected issues should be formulated in the form of a question, or hypothesis, namely a statement (statement) as a temporary answer to questions.

The teacher's activity in data collection step was that guide the students to look for other sources rather than read a single text book only. The other sources were as opening dictionary and book, internet surfing, dividing the students into groups to have discussion, and guiding them to write report text. These represented that the teacher 
has guided the students. It was line with Harmer (2004, p.41) the role of teacher in teaching writing are motivating and supporting. It is recomended that the teacher should add some activities related to teaching writing such as 1) giving the examples of various report texts to each group; 2) asking the students to label pronoun, circle adjectives in texts and give triangle fo verbs (Direktorat Pembinaan Sekolah Menengah Pertama, 2013, p.5).

When the ongoing exploration, teacher provided an opportunity for students, so according to Shah (2004, p. 244) it gathers as much information relevant to prove whether or not the hypothesis. In line with Djamarah (2002 , p. 22), teacher serve the question or do not prove the hypothesis, so the students are given the opportunity to collect (collection) of various relevant information, read the literature, observing the objects, interviews with sources, conduct their own trials and so on. The consequences of this step was that students learn actively to find something related to the problems faced, thus it inadvertently connected students with the knowledge problem that has been owned.

In data processing, students did the process data that were collected then they were written as a product of their writing project. It is in line with Shah $(2004$, p. 244) that the data processing is an activity of process data and information that has been obtained by the students through interviews, observation, and so on, then interpreted. All informal readings, interviews, observation, and so on, all processed, randomized, classified, tabulated, even if need be calculated and interpreted in a certain way at a certain confidence level (Djamarah, 2002, p. 22).

In the group, they performed their tasks in front of class by a student in each of group who felt interested in talking or presenting the task. Here, the sort of performing task divided into three forms namely spoken, written, and project. It was conducted to accomodate several of students' abilities because every students was unique. They had various abilities. The students who felt comfortable in writing were guided to do the writing task. In contrast, for those who were interested in talking, the suggested task wa speaking. Moreover, for those who felt easy in making the product, the teacher asked them to 
print the results of their writings and made a project. Here, students also did the coding or categorization that served as the formation of concepts and generalizations individually. The generalization of the student got a new knowledge about alternative answers or settlement that needs proof logically.

From the description above, it could be concluded that the teacher facilitated the students to express their learning style. It is in line with Brown (2011, p.340) that a teacher is a facilitator who facilitates the proper task. Furthermore, the teacher also provided useful experience. It expexcted to gain competence in data processing step. The competence which is developed in this activity was to develop attitudes of honesty, through, tolerance, the ability of systematically thinking. It is to express their opinion briefly and to develop good and correct language skill (Kementrian Pendidikan dan Kebudayaan, 2013d).

It also could be discussed that in verification step, the teacher gave correction and feedback in the students' task of group work and individual work. This was appropriate to Harmer (2004, p.41) that one of the roles of teacher is to respond to the students. The meaning of respond is to react to the content and construction of a performing task and make suggestion for its improvement. It is in line with Bruner in Budiningsih (2005, p. 41), aims to make the process of learning will go well and creative if the teacher gives students the chance to find a concept, theory, rules or understanding through examples that he encountered in his life. So, after reaching that goal or based on the results of processing and interpretation, or the information, statements or hypotheses that have been formulated earlier was then checked, whether answered or not, whether proven or not (Djamarah, 2002, p. 22).

In generalization step, teacher and students drew the conclusion. It was the process could be used as a general principle and applied to all events or similar problem, with regard to the outcome of verification. It was in line with Djamarah (2002, p. 22) that based on the results of the verification stage earlier, students learned to draw certain conclusions or generalizations. Finally, it formulated in words the principles that underlied generalizations. 
Noteworthy, student mastered the meaning and the rules or principles about the whole information of the report text and they also could write the report using the right generic stucture. It was like Slameto (2003, p. 119) said that the extensive experience of a person, as well as the importance of the regulatory process and the generalization of these experiences. By capturing the characteristics or properties of the general nature is contained in a number of specific things (Djamarah, 2002, p. 191).

Through the whole of implementation of DL teaching and learning process, it could be encouraged students in their critical thinking. Of course, students could be encouraged and stimulated to write report text. It was in line of Barry K. Beyer (1995) which said that critical thinking means making clear, reasoned judgments. During the process of critical thinking, ideas should be reasoned and well thought out/judged. The National Council for Excellence in Critical Thinking (2008) defines critical thinking as:

The intellectually disciplined process of actively and skillfully conceptualizing, applying, analyzing, synthesizing, and/or evaluating information gathered from, or generated by, observation, experience, reflection, reasoning, or communication, as a guide to belief and action.

The list of core critical thinking skills includes observation, interpretation, analysis, inference, evaluation, explanation, and metacognition. Students do all the activities in the implementation of DL in teaching and learning report writing.

\section{STUDENTS' RESPONSES TOWARDS DL DURING THE TEACHING LEARNING OF REPORT WRITING}

It could be looked from the observation data in the implementation of report writing using DL above, that students had good entusiast and struggle in learning report writing using DL. How did say like that? Because they did the teaching learning using DL process till producing the writing product. However, the process was long and consisted of six steps. In fact, it made tried but they did not. They did the steps as enjoy as possible. The factor was the teacher. He could run the DL well. 
In order to support the data of the implementation of DL, it was important to add students' responses in learning report writing text. The students' responses were obtained from students' behaviors while they were in the teaching and learning process as well as being interviewed. Moreover, the researcher took seven samples of students. Furthermore, the result of observation and interview was devided into six sections. Those were students' responses to the implementation of stimulation, problem statement, data collection, data processing, verification, and generalization. The students' responses toward the implementation of DL are presented below:

\section{Stimulation}

In the observation before, it could be seen that students interested in stimulation step because the topic interconnected with their daily life. Teacher also asked them to sing a song about the topic.

Based on the data that has been obtained in the interview, the data illustrated that almost all students were delighted with the various reasons which they stated in the interview. It can be concluded that students' responses in the learning step of stimulation done by the teacher was effective. It can be proven from the results of the interview.

In giving stimulation, teacher used the topic that made students in Junior High School interested. The topic was about whatever around them, that was wild life, fruit, electronic media, and natural disaster that were known by them. They were familiar with all of the topics. It could be called with contextual topics. So that, they were enthusiastic and curious in the following stimulation, in spite of there were some of them still had questions in their mind what the material that would be learned.

In the other data interview, researcher got the reason why students were interested with the stimulation was because teacher gave the picture, song, short poem. The data could be seen before in data interview 1 explained in the implementation of report writing using DL. It could be disscussed that students' response toward implementation report writing using stimulation step of DL was good 
enough. All students were delighted with the various reasons which they stated in the interview.

\section{Problem Statement}

According to data collection technique in observation, in problem statement step students had the entusiasm in the activities. They got the model of text which made them were curious before, what text would be learned. With the model text, they got the clue, what text it was. Within the problem statement step, the students had their own opinions as well as regarding activities they had there. The opinions were the gates to seek the detailed information of the learning step based on their prespectives.

According to the interview data, some of students knew about the material and some of them were not know about it. It becaused every students had difference language sensitivity. Some of them learned before the class be started, some of them did not. But, they had high confident to continuo the lesson and had high curiosity. Therefore, they did not less in the activities. It made them had more spirit because the picture were contextual. It could be illustrated that the students' responses in problem statement step of DL implementation were effective.

\section{Data Collection}

In data collection step, the teacher increased the students' critical thinking to analyse the text with their own knowledge. They has already learned about the kinds of text before, so they had picture of their mind about the questions given. Students were given the opportunity to collect much relevant information, read the literature, observe the objects, interview with sources, and conduct their own trials and so on. All of the activities made them were challenging.

To seek for more detailed data of the students' responses regarding the data collection step, there were some of the students who were asked to take part in the interview. There were seven interviewees involved.

Based on the data that have been obtained at the interview technique, it effective. The fact was illustrated in the results of interview. The factor that made the students active in the step was 
because of the teacher behavior. He guided the students to search the information as many as possible from many resources they had. They could search from the book, dictionary, alfa link, google, interview with friends, and others. He also went around the students to become a facilitator for their students.

\section{Data Processing}

Students learned to process the data collection to produce the concepts about report text in group and produce the report writing individual. It could be illustrated that the activities needed extra thinking to get the target. When they processed the data, researcher looked that they were clever but the time was limited them in the processing the data. The table mapping mapped their activity but the fourth columns must be filled by them. The other reason was becaused the ability and capability of each student was different. Some of them were fast in processing; some of them were also slow in that step. It illustrated that it was less effective because of the time and each of their capabilities. Actually, teacher could devide the DL process in more meeting.

Based on the data that have been obtained at the interview technique, it can be said that students less interest with writing English but they want to try to do it. They tried to search the data as many as possible then they compared the data with the grammar focus used in report writing. One of the factor they still had needed to try was the teacher. He made the table mapping to make students always minded about what was the topic they would write, what was the generic structure of report writing, what were the appropriate vocabularies for their writing, and what the right grammar must be used. But, the factor was the time management. Actually, it was enough because the time was 20 minutes. So, it could be found that the factor was also ability and capability of each student was different.

\section{Verification}

The students got directly correction from the teacher. He gave the comments from each of the group performance but did not the students' individually report writing because of the time was limited. 
To give more detail of students' responses in conducting verification step, the interview technique was carried out. The interview data were collected from seven students. Moreover, the interview was done individually.

Based on the data that had been obtained at the interview technique, it can be said that students had been satisfied with the score of their work. They were entusiast to know about the result for evaluating themselves, so they could adjust the shortage before. One factor that made them had high entusiast were because the teacher. $\mathrm{He}$ always gave the motivation words in the duty of every students. He was fast in giving assessment because he always observed their students one by one every meeting. Therefore, he knew about each of their students well. It could be concluded that the students' responses for verification step were entusiast.

\section{Generalization}

The students had deep understanding about report text and had be able to write well by themselves. They also became an active students. It indicated that they got the quality of their ability and capability in exploring outside the classroom. And the interview data of the generalization step was carried out because to complete the steps and the interviewe data.

Based on the data that had been obtained at the observation and interview techniques, it could be said that students had been satisfied with the conclusion which they got from their teacher or friends. They were entusiast to know about the result for conclusion, because all of them had already searched the data by themselves. Then, they must get the conclusion for getting the generalization step in implementation of DL. Therefore, it indicated that the students' responses of generalization step were good. The generalization did on the right track and students became active students of the whole activities using DL in teaching and learning process of report writing.

To map the student's responses of the whole steps, researcher put it into the summary table like in the following table 2: 
Table 2 Summary Table of Students' Responses in Implementation of DL in Teaching Report Writing

\begin{tabular}{|c|c|c|c|}
\hline Step & $\begin{array}{l}\text { Students' } \\
\text { Responses }\end{array}$ & Activities & Note \\
\hline Stimulation & $\begin{array}{l}\text { They were } \\
\text { interested }\end{array}$ & $\begin{array}{l}\checkmark \text { Teacher used } \\
\text { pictures, song, and } \\
\text { poem }\end{array}$ & Positive \\
\hline $\begin{array}{l}\text { Problem } \\
\text { Statement }\end{array}$ & $\begin{array}{l}\text { They were } \\
\text { enthusiast and } \\
\text { curious }\end{array}$ & $\begin{array}{l}\checkmark \text { Teacher gave the } \\
\text { guessing questions, } \\
\text { gave the clue, then } \\
\text { gave the model of } \\
\text { text }\end{array}$ & Positive \\
\hline Data Collection & $\begin{array}{l}\text { They were happy } \\
\text { and felt the } \\
\text { activity was } \\
\text { effective }\end{array}$ & 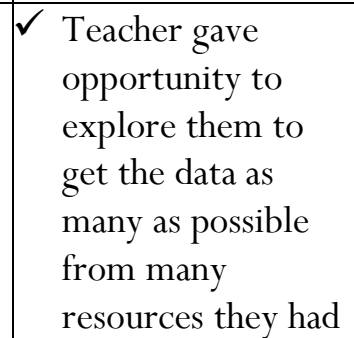 & Positive \\
\hline Data Processing & $\begin{array}{l}\text { They were less } \\
\text { disappointed }\end{array}$ & $\begin{array}{l}\checkmark \text { Teacher gave the } \\
\text { limited time }\end{array}$ & Negative \\
\hline Verification & $\begin{array}{l}\text { They were } \\
\text { entusiast to know } \\
\text { about the result } \\
\text { for evaluating } \\
\text { themselves, so } \\
\text { they could adjust } \\
\text { the shortage } \\
\text { before } \\
\text { They were thank } \\
\text { for the result of } \\
\text { their efforts }\end{array}$ & $\begin{array}{l}\text { Teacher gave } \\
\text { corrections, score, } \\
\text { and comment for } \\
\text { their task result }\end{array}$ & Positive \\
\hline Generalization & $\begin{array}{l}\text { They were } \\
\text { satisfied }\end{array}$ & $\begin{array}{l}\checkmark \text { They got the } \\
\text { concept just not } \\
\text { the hypothesis }\end{array}$ & Positive \\
\hline
\end{tabular}


The summary table above showed the whole of students' responses of the DL implementation in teaching and learning process in writing report text. It concluded that in five steps, students had good responses and in just one step, students felt less disappointed.

From the observation and the interview data, all students were delighted with the various reasons which they stated in the interview. It could be concluded that students' responses in the learning step of stimulation done by the teacher was effective. Teacher used the topic that made students in Junior High School interested that were known by them. So that, they were enthusiastic and curious in the following stimulation, in spite of there were some of them still had questions in their mind what the material that would be learned. Students were interested with the stimulation was because teacher gave the picture, song, short poem. It could be disscussed that students' response toward implementation report writing using stimulation step of DL was good enough.

According to the interview data, some of students knew about the material and some of them were not know about it. It becaused every students had difference language sensitivity. Some of them learned before the class be started, some of them were not. But, they had high confident therefore they did not less in the activities. It made them had more spirit because the picture were contextual. It can be illustrated that the students' responses in problem statement step of DL implementation were effective.

It could be said that students' responses in learning step of data collection were effective. The fact was illustrated in the results of interview. The factor made students were active in the step was because of the teacher behavior. He guided the students to search the information as many as possible from many resources they had. They could search from the book, dictionary, google, interview with friends, and others. He also went around the students to become a facilitator for them.

Students were less interest with writing English but they want to try to do it. They tried to search the data as many as possible then they compared the data with the grammar focus used in report writing. One of the factor they still had needed to try was the teacher. He made 
the table mapping to make students always minded about what was the topic they would write, what was the generic structure of report writing, what were the appropriate vocabularies for their writing, and what the right grammar must be used.

Students had been satisfied with the score of their work. They were entusiast to know about the result for evaluating themselves, so they could adjust the shortage before. One factor that made them had high entusiast were because the teacher. He always gave the motivation words in the duty of every students. He was fast in giving assessment because he always observed their students one by one every meeting. Therefore, he knew about each of their students well.

Students had been satisfied with the conclusion of they got from their teacher or friends. They were entusiast to know about the result for conclusion, because all of them had already searched the data by themselves. Then, they must get the conclusion for getting the generalization step in implementation of DL.

\section{CONCLUSION}

It can be concluded some following imprortant information that the teacher implemented all six steps of DL, 1) stimulation, 2) problem statement, 3) data collection, 4) data processing, 5) verification, 6) generalization.

The activity of stimulation step was that the teacher gave the questions about a general topic interconnected with report text. He was also presenting picture. He did not introduced the topic directly. Whereas the activity of problem statement was that the teacher presented pictures using text to help students' general image to communicate meaningfully as a model of a certain report text.

The activity of data collection step was that guided the students to look for information as many as possible from dictionary, book, internet, discussion, and guided them to write report text.

The activity of data processing step was that the students performed their tasks in front of class by one of students from each of group. Students also did the coding or categorization that served as the formation of concepts and generalizations individually. In data processing, students had the dificulties of process the data because the 
limitation of time, students wrote whatever they found as the data must be processed. Clever students were faster than unclever students, but all of them could get the good report writing. All of them got high score, did not get under the standard score.

The activity of verification step was that the teacher gave correction and feedback in the students' task of group work and individual work. He gave the motivational comments to the students. Difference with the activity of generalization was that the teacher and students drew the conclusions. Finally, it formulated in words the principles that underlied generalizations.

All of the six steps of DL implementation were relevant with the theories. Stimulation step helped students' identifying topic, encouraged the students to write, and assisted students to explore in achieving the goal. After that, problem statement step helped students to know the process of writing report text through the model text. Data collection step gave opportunity to students to explore as could as possible while data processing step gave opportunity to students to process the data. Verification step gave opportuity to students to get correction then generalization step gave opportunity to students to get the concept just not the hypothesis.

The students' responses were good enough in five steps. They were stimulation, problem statement, data collection, verification, and generalization. In contrast, the sudents' responses in data processing was unsatisfied because of limited time and difficulty in processing the data.

The students' writing were good in the content, whereas some of them have a bad concord of the content. There were good in selecting and written words, but there were not. Some of the grammar used was right, some of it was not. In all of the writing, teacher gave his comment. It made his students high attention to their result, and knew their mistakes for correction. It could be said with motivational correction. All of the students got the score up to the standard score.

\section{REFERENCES}

Alhasony, M. (2012). Vocabulary Discovery Strategy Used by Saudi EFL Students in an Intensive English Language Learning 
Context. International Journal of Linguistic, 4 (2) accessed from macrothink.org/journal/index.php/pdf on November, $25^{\text {th }}$ 2014.

Alma, B., et al. (2010). Teachers Mastering the methods and Skilled Teaching. Bandung: Publisher Alfabeta.

Arikunto, S. (2010). Prosedur Penelitian: Suatu Pendekatan Praktik. Jakarta: RinekaCipta.

Ary, D., Jacob, L. C., \& Sorensen, C. (2010). Introduction to Research in Education. California: Wadsworth.

Aswandi \& Zuichri, F. (2009). Teaching Writing. Surabaya: Unesa University Press.

Bogdan, R. C. \& Biklen, S. K. (2007). Qualitative Research for Education (5 thed.). Boston: Pearson Education, Inc.

Brown, D. (2000). Principles of Language Learning and Teaching, Fourth Edition. New York: Addison Wesley Longman, Inc.

Bruner, J. (1961). The Act of Discovery. Harvard Educational Review. 31 (1): 21-32 accessed on October, $20^{\text {th }} 2014$.

Cahyaningsih, R. (2013). Process Approach as a Means of Improving the Students' Writing Ability of the Junior High School. (Pascasarjana), Universitas Surabaya, Surabaya.

Caprario, M. (2013). Guided Discovery Grammar Instruction: A Review of the Literature with Original Teaching Materials. MA TESOL, 689, accessed from http://digitalcollections. sit.edu/ipp collection/689/ on November $25^{\text {th }} 2014$.

Clark, I. L. (2003). Concepts in Composition: Theory and Practice in the Teaching of Writing. London: Lawrence Elrbaum Associates Publishers.

Department for Education and Development. (2011). Engaging in and Exploring Report Writing. Government of South Australia.

Goh, C. C. M. \& Silver, R. E. (2004). Language Acquisitionand Development. Singapore: Prentice Hall Pearson Education South Asia Pte Ltd. 
Harmer, J. (1998). How to Teach English: An Introduction to the Practice of English Language Teaching. England: Adison Wesley Longman Limited.

. (1991). The Practice of English Language Teaching. Longman Handbooks for Language Teachers.

. (2004). How to Teach Writing. London: Pearson Education Limited.

Hasan, N. (2014). Teaching Vocabulary through Collaboration: Students as Independent Reader. Journal of Education and Practice, 5(13) accessed on, November, $20^{\text {th }} 2014$.

Hedge, T. (2000). Teaching and Learning in the Language Classroom. Oxford: Oxford University Press.

Kemendikbud. (2013a). Peraturan Menteri Pendidikan dan Kebudayaan no.65 tentang Standar Proses Pendidikan Dasar dan Menengah. Jakarta: Depdikbud.

. (2013c). Peraturan Menteri Pendidikan dan Kebudayaan

No.68 tentang Kerangka Dasar dan Struktur Kurikulum Sekolah Menengah Pertama/ Madrasah Tsanawiyah (Number 68, 2013). Jakarta: Depdikbud.

. (2013d). Peraturan Menteri Pendidikan dan Kebudayaan no.

81A Tahun 2013 Tentang Implementasi Kurikulum 2013. Jakarta: Depdikbud.

. (2013f). Salinan Lampiran Peraturan Menteri Pendidikan dan Kebudayaan RI Nomor 65 Tahun 2013 Tentang Standar Proses Pendidikan Dasar dan Menengah. Jakarta: Kementerian Pendidikan dan Kebudayaan.

Kurniasih, I. \& Sani, B. (2014). Implementasi Kurikulum 2013: Konsep dan Penerapan. Surabaya: Kata Pena.

Latif, M. A. (2014). Research Methods on Language Learning: An Introduction. Malang: UniversitasNegeri Malang Press.

Lestari, L. A. (2008). The Interactional Approach to the Teaching of Writing and Its Implications for Second Language Acquisition. TEFLIN Journal Vol.14 No.1 
Lie, A. (2007). Education Policy and EFL Curriculum in Indonesia: Between the Commitment to Competence and the Quest for Higher Test Score. TEFLIN Journal, Vol. 18, No.1 pp.1-13.Retrieved from www.journal.teflin.org, on January $20^{\text {th }}, 2015$.

Mc Millan, J. H. (2008). Educational Research Fundamentals for Consumers $\left(5^{\text {th }}\right.$ ed. $)$. new York: Pearson Education, Inc.

Miles, H. \& Saldana. (2014). Qualitative Data Analysis: A Methods Sourcebook ( $3^{\text {rd }}$ ed.). Washington DC: Sage Publications, Inc.

Ministry of Education and Culture. (2014). Training Module Implementation of 2013 junior English curriculum. Jakarta: Human Resources Development Agency of Education and Culture and Education Quality Assurance Ministry of Education and Culture. . (2014). Regulation of the Minister of Education and Culture of theRepublic of Indonesia Number 58 of 2014 on Kurkulum 2013 School SMP / MTs.

Mulyasa, H. E. (2013). PengembangandanImplementasiKurikulum 2013. Bandung: PT. Rosdakarya.

Nunan, D. (1998). The Learner-Centered Curriculum. Cambridge: Cambridge University Press.

O’Malley \& Pierce. (1996). Authentic Assessment for English Language Learner. USA: Addison-Wesley Publishing Company Inc.

Peraturan Menteri Pendidikan dan Kebudayaan. (2013). Standar Proses. Jakarta: Permendikbud 65B.

(2013). Nomor 70. Kerangka Dasar dan Struktur Kurikulum Sekolah Menengah Kejuruan/ Madrasah Aliyah Kejuruan. Jakarta: Mendikbud.

Putra, K.A. (2014). The implication of Renewal Curriculum on ELT in Indonesia. Parole Journal of Linguistics and Education.Vol.4, Number 1. Pp.63-75. Retrieved from www.ejournal.undip.ac.id, on February $21^{\text {st }} 2015$.

Richards, J. C. (2006). Communicative Language Teaching Today. Cambridge: Cambridge University Press. (2006). Curriculum Development in Language Teaching. Cambridge: Sambridge University Press. 
Reppen, R. (2002). A Genre-Based Approach to Content Writing Instruction in J.C. Richards \& W.A. Renandya (Eds.), Language Teaching: An Anthology of Current Practice. Cambridge: Cambridge University Press.

Sari, R. N. \& Kusumarasdiyati. (2014). The Implementation of Guided Discovery Learning To Teach Reading Of Narrative Text To Tenth Graders. Journal Universitas Negeri Surabaya. Retrive from http: / /www.scribd.com/doc/245054916 on Agust 2015.

Sarwono, J. (2006). Metode Penelitian Kuantitatif dan Kualitatif. Yogyakarta: Graha Ilmu.

Savignon, S. (1997). Communicative Competence: Theory and Classroom Practice Texts and Contexts in Second Language Learning. New York: Cambridge University Press. Lewis. Michael. 1993. The Lexical Approach. Hove: Language Teaching Publications.

Sudjana, N. \& Ibrahim. (2012). Penelitian dan Penilaian Pendidikan. Bandung: Sinar Baru Algensindo.

Syah, M. (2004). Psikologi Pendidikan Suatu Pendekatan Baru. Bandung: PT Remaja Rosdakarya.

Wasimin. (2014). Penerapan Model Discovery Learning Dalam Pembelajaran Bahasa Inggris Smp Dalam Penerapan Kurikulum 2013. Widyaiswara LPMP: Central Java.

Widayanti, A. (2011). Improving Student's Ability in Writing recount Text using Picture Series. (Pascasarjana)., Universitas Surabaya, Surabaya.

Yin, R. K. (2001). Qualitative Research from Start to Finish. New York: Guilford Press 